\title{
Supplementary heat requirements when brooding tom turkey poults
}

\author{
S. Gencoglan ${ }^{1}$, C. Gencoglan ${ }^{2 \#}$ and A. Akyuz \\ ${ }^{1}$ Ministry of Agricultural \& Rural Affairs, Provincial Agricultural Directory, Kahramanmaras, Turkey \\ ${ }^{2}$ Department of Agricultural Engineering, Faculty of Agriculture, University of Kahramanmaras Sutcu Imam, \\ Kahramanmaras, Turkey
}

\begin{abstract}
In this study, the supplementary heat required when brooding turkey poults in winter and summer in the Kahramanmaras region of Turkey was determined using a heat and humidity balance method for a naturally ventilated house with a capacity of 6500 tom turkey poults. In the calculation of heat and humidity balance, temperature values, sensible heat and moisture production of tom turkey poults were taken from the American Society of Agricultural Engineers (ASAE) standards for corresponding turkey poult weights, and outside long term (1980 - 2005) monthly average temperatures were obtained from a local climate station. The coldest and warmest crucial months were determined as January $\left(6.5{ }^{\circ} \mathrm{C}\right)$ and August $\left(29.2{ }^{\circ} \mathrm{C}\right)$, respectively. When brooding was initiated in the first week of January, supplementary heat was needed for the subsequent five weeks, being 32937, 27028, 21721, 9476 and $5400 \mathrm{~W}$ per week, respectively. When brooding started in the first week of August, poults needed only $5544 \mathrm{~W}$ supplementary heat. However, tom turkey poults would nevertheless benefit from supplementary heat during this period because they are not yet fully feathered and the digestive system has not yet fully developed.
\end{abstract}

Keywords: Heat-humidity balance, supplementary heat, agricultural building

${ }^{\#}$ Corresponding author. Email: gencoglan@ksu.edu.tr

\section{Introduction}

Environmental conditions such as ambient temperature, relative humidity (RH), air movement, lighting, sensible heat and moisture production of animals inside poultry houses are the most important factors influencing poultry development and production. Temperature is one of the most important factors among the environmental conditions. The temperature range where the sensible heat loss of the animal remains fairly constant is the thermal zone where the most efficient feed conversion will occur. Below this temperature, lower critical temperature, the animal will use feed energy especially to maintain body temperature. The critical temperature is the point where metabolic heat production increases to maintain a constant body temperature and, therefore, environmental temperature should not be allowed to go below the critical temperature to maintain efficient growth. Turkey poults are sensitive to environmental temperature with a lower critical temperature of about $29^{\circ} \mathrm{C}$ (Scott et al., 1983). Therefore, feed conversion declines below the critical temperature. In a hot environment, energy intake declines, and rate of productive performance will consequently decrease (Osbaldiston \& Sainsbury, 1963; Ernst, 1995).

When the air temperature in the poultry house is low, feed intake increases. The extra energy is used to maintain body temperature in the physiological range, instead of utilising it for gaining weight (Hurwitz \& Bengal, 1982; Scott et al., 1983; Yahav et al., 1996). Conversely, at a high inside air temperature, both weight gain and feed intake decline significantly (Yahav et al., 1997). Similarly, it is reported that lower weight gains of broilers at high temperatures are directly associated with decreased feed intake, and losing heat to the environment becomes increasingly difficult when RH is high (Borges et al., 2003); for example, Yalcin et al. (1997) reported decreases of 23\% in body weight and $15 \%$ in food consumption of poults reared at high temperatures. As a consequence of increased environmental temperature, the internal body core and skin temperature of the bird increases. The bird begins to breathe more rapidly, while its heart rate and oxygen consumption increase. The increase in oxygen consumption is a direct reflection of the increased energy demand for maintenance due to panting (Miles, 1999). Turkeys cannot tolerate a concurrent high temperature and high humidity. When the surrounding air is moist, it cannot absorb as much moisture from the lungs; consequently the bird must pant faster. Similarly, when the outside temperature is high, respiratory rate is increased. With both high temperature and high humidity the bird may not be able to pant fast enough 
to remove the heat from its body (El Boushy \& Van Marle, 1978). The increase in the breathing rate is accompanied by an increase in the loss of moisture from the body. To compensate for this loss, the bird drinks more water to avoid dehydration. Eventually, the bird drinks more water than it can exhale, and the surplus is excreted through the droppings. The amount of moisture in the ambient air (humidity) also affects the panting rate; the higher the humidity the more rapid the respiration (North, 1984). Consequently, either at low or high inside air temperature, the rate of productive performance of turkey poults decreases. Therefore, inside air temperature when brooding turkey should be kept at an optimal level (Konca, 2001) by reducing heat loss and using supplementary heating when needed (Anonymous, 1987).

Poults are usually placed in brooder rings for the first five to six days. In general, each heater is set at a temperature of 32.2 to $35{ }^{\circ} \mathrm{C}$ at floor level below the heater, and a room temperature of $23.9{ }^{\circ} \mathrm{C}$ when the poults arrive. The temperature is lowered $2.8{ }^{\circ} \mathrm{C}$ per week for the next three weeks (Stull, 1998). Temperatures near the floor of the room outside the brooding area should be maintained at between 21.1 and $23.9^{\circ} \mathrm{C}$ for the first week and be gradually reduced to between 12.8 and $15.6^{\circ} \mathrm{C}$ (Arrington, 1980).

Researchers such as Haartsen (1981), Charles (1981), Konca (2001), Bolla (2005) and Turkoglu et al. (2005) reported that a starting temperature for turkey brooding should be between 33 and $36{ }^{\circ} \mathrm{C}$ in brooder rings below radiant brooders, and that temperatures near the floor of the room outside the brooding area should be between 29 and $32{ }^{\circ} \mathrm{C}$. This temperature should be reduced $2-3{ }^{\circ} \mathrm{C}$ every week until a temperature of $17-21^{\circ} \mathrm{C}$ is reached. Hurwitz et al. (1980) reported that weight gain in young turkeys was highest around $20^{\circ} \mathrm{C}$ with an asymmetrical decrease on either side of this temperature.

The requirement of supplementary heat when brooding tom turkeys, will vary in accordance with the insulation of the house, animal heat production as a function of age and density of poults and growing season. Moreover, the climatic condition of the region for which the tom turkey house is planned has to be taken into consideration.

The Kahramanmaras region of Turkey has Mediterranean climatic conditions with hot and dry summers, and rainy and warm winters. High wind speeds $(4.9-6.7 \mathrm{~m} / \mathrm{sec})$ and high frequency of winds (288 - 432 times) in summer are typical characteristics of this region. The aim of this study was to estimate the supplementary heat requirement to optimise environmental conditions inside the tom turkey house using a local heating system. This may be accomplished by determining crucial months within the year and calculating the required supplementary heat using a heat and humidity balance method in order to prevent excessive temperature.

\section{Materials and Methods}

In order to plan a natural ventilated house with a capacity of 6500 tom turkey poults and to calculate required supplementary heat, various project criteria were used to provide optimum environmental conditions.

Areas of $0.05 \mathrm{~m}^{2}$ per $0-4$ week-old tom turkey poult and $0.11-0.12 \mathrm{~m}^{2}$ per $5-8$ week-old poult are considered adequate, according to Arrington (1980) and Turkoglu et al. (2005). Assuming a width of $10 \mathrm{~m}$ net space (Ozen, 1992; Ernst, 1995), the length of the tom turkey house was estimated to be $75 \mathrm{~m}$ based on an area of $0.115 \mathrm{~m}^{2}$ per $5-8$ week old poult. The following was also considered: minimum $0.29 \mathrm{~m}^{3}$ of inside air volume per 8 week old poult (Alagoz, 1983), $2.75 \mathrm{~m}$ wall height (Okuroglu \& Delibas, 1987), total windows area as $15 \%$ of the floor area and $23^{\circ}$ gable roof angle (Ones \& Olgun, 1989). The house was oriented east and west. Other data for structural elements are summarized in Table 1.

The following equations were used to calculate general heat balance for the tom turkey poult house (Carr, 1980; Balaban \& Sen, 1988; Ibrahim et al., 1991; ASAE, 1996; Lidley \& Whitaker, 1996).

$$
\mathrm{Q}_{\text {sup }}+\mathrm{Q}_{\mathrm{m}}+\mathrm{Q}_{\text {additional }}=\mathrm{Q}_{\mathrm{e}}+\mathrm{Q}_{\mathrm{v}}+\mathrm{Q}_{\text {stored }}
$$

Where $\mathrm{Q}_{\text {sup }}$ is supplementary heat $(\mathrm{W}), \mathrm{Q}_{\mathrm{m}}$ is the sensible heat dissipated by the tom turkey poults (W), $\mathrm{Q}_{\text {additional }}$ is the heat produced by other sources such as heat production rate by equipment, i.e. motors, lights etc., (W) (small, negligible term), $\mathrm{Q}_{\mathrm{e}}$ is the net heat output through the structural elements (roof, wall, window, door) (W), $\mathrm{Q}_{\mathrm{v}}$ is the heat output through ventilation $(\mathrm{W}), \mathrm{Q}_{\text {stored }}$ is rate heat stored or released by building materials (W) (small, negligible term). 
Table 1 Specifications for the structural elements of the planned tom turkey poult house

\begin{tabular}{llcc}
\hline $\begin{array}{l}\text { Structural } \\
\text { elements }\end{array}$ & Structural materials used & \multicolumn{2}{c}{ Area of structural elements $\left(\mathrm{m}^{2}\right)$} \\
\cline { 3 - 4 } Floor & Hard core and $2.5 \mathrm{~cm}$ concrete skim & $0-4$ weeks & $5-8$ weeks \\
Walls & 40x20x20 cm briquette, both side $2 \mathrm{~cm}$ plaster & 168 & 750 \\
Roof & Asbestos, glass wool, bitumen felt, wooden cover & 365 & 370 \\
Door & Wood & 2.2 & 833 \\
Window & Wooden frame, 3 cm glass & 49.5 & 8.2 \\
Curtain & 0.1 cm PVC curtain & 38.4 & 112.5 \\
\end{tabular}

Then, rearranging equation 1 , equation 2 could be written as:

$$
\mathrm{Q}_{\text {sup }}=\left(\mathrm{Q}_{\mathrm{e}}+\mathrm{Q}_{\mathrm{v}}\right)-\mathrm{Q}_{\mathrm{m}}
$$

Equation 2 may not provide heat balance in the tom turkey poult house all the time. There is a heat deficit if $\mathrm{Qm}$ is less than $\mathrm{Q}_{\mathrm{e}}+\mathrm{Q}_{\mathrm{v}}$ on the right hand side of equation 2. In that case, supplementary heat is required to raise the temperature to an optimal level. Excess heat is indicated when $\mathrm{Q}_{\mathrm{m}}$ is greater than $\mathrm{Q}_{\mathrm{e}}+\mathrm{Q}_{\mathrm{v}}$. This extra heat should be removed by ventilation.

Heat loss $\left(Q_{e}\right)$ through structural elements can be calculated by using the equation (CIGR, 1984; Albright, 1990):

$$
Q_{e}=\sum_{i=1}^{n} U_{i} A_{i} \Delta t
$$

Where $U$ is the coefficient of heat conductance of structural elements $\left(\mathrm{W} / \mathrm{m}^{2}{ }^{\circ} \mathrm{C}\right), \mathrm{A}$ is the surface area of structural elements $\left(\mathrm{m}^{2}\right)$ in Table $1, \Delta \mathrm{t}\left(\mathrm{t}_{\mathrm{i}}-\mathrm{t}_{\mathrm{o}}\right)$ is the difference between inside $\left(\mathrm{t}_{\mathrm{i}}\right)$ and outside $\left(\mathrm{t}_{\mathrm{o}}\right)$ temperature of tom turkey house $\left({ }^{\circ} \mathrm{C}\right)($ Table 3$)$.

Heat loss $\left(Q_{v}\right)$ removed by ventilation was calculated using equations 4 and 5 (ASAE, 1996):

$$
\begin{aligned}
& \mathrm{Q}_{\mathrm{v}}=0.341 \mathrm{Q}_{\min } \Delta \mathrm{t} \\
& Q_{\min }=\frac{W_{a}}{g_{i}-g_{o}}
\end{aligned}
$$

Where $\mathrm{Q}_{\min }$ is the minimum ventilation discharge rate $\left(\mathrm{m}^{3} / \mathrm{h}\right) ; \mathrm{W}_{\mathrm{a}}$ is the released total moisture in the inside air $(\mathrm{g} / \mathrm{h}) ; \mathrm{g}_{\mathrm{i}}$ and $\mathrm{g}_{\mathrm{o}}$ are absolute air moisture $\left(\mathrm{g} / \mathrm{m}^{3}\right)$ inside and outside the house.

The coefficient of total heat conductance of structural elements $\left(\mathrm{U}, \mathrm{W} / \mathrm{m}^{2}{ }^{\circ} \mathrm{C}\right)$ was calculated using the following equation.

$$
\begin{aligned}
& \mathrm{U}=\frac{1}{\frac{1}{\mathrm{f}_{\mathrm{i}}}+\sum_{\mathrm{m}=1}^{\mathrm{n}} \frac{\mathrm{d}_{\mathrm{m}}}{\mathrm{c}_{\mathrm{m}}}+\frac{1}{\mathrm{f}_{\mathrm{o}}}} \\
& \mathrm{R}=\frac{1}{\mathrm{U}}
\end{aligned}
$$

Where $R$ is the coefficient of thermo resistance $\left(\mathrm{m}^{2}{ }^{\circ} \mathrm{C} / \mathrm{W}\right) ; \mathrm{f}_{\mathrm{i}}$ and $\mathrm{f}_{\mathrm{o}}$ are the surface coefficients of inside and outside heat conductance of structural elements $\left(\mathrm{W} / \mathrm{m}^{2}{ }^{\circ} \mathrm{C}\right), \mathrm{d}_{\mathrm{m}}$ and $\mathrm{c}_{\mathrm{m}}$ are thickness of structural elements (m) and thermal conductivity $\left(\mathrm{W} / \mathrm{m}^{\circ} \mathrm{C}\right)$, respectively. 
Coefficient of total heat conductance of structural elements $\left(U_{\max }\right)$ is defined as the coefficient which is calculated from inside temperature and $\mathrm{RH}$ at which there is no condensation on the surface of structural elements, which may be calculated using the following equation by Balaban \& Sen (1988):

$$
\mathrm{U}_{\max }=\frac{\mathrm{f}_{\mathrm{i}}\left(\mathrm{t}_{\mathrm{i}}-\mathrm{t}_{\mathrm{d}}\right)}{\Delta \mathrm{t}}
$$

Where $t_{d}$ is the inside surface dew-point-temperatures of structural elements $\left({ }^{\circ} \mathrm{C}\right)$. In this calculation the inside surface dew-point temperatures of structural elements according to inside $65 \% \mathrm{RH}$ and inside air temperature of house were taken from Balaban \& Sen (1988), and inside and outside air temperature were taken from Table 3.

The thickness of the insulation material of roof was calculated using data in Table 2. Heat losses through window, door, wall and curtain, except roof, were calculated using equation 3 for the first week of January, given in Table 4. Heat loss permitted through the roof was estimated by subtracting heat losses through ventilation $\left(Q_{v}\right)$ and structural elements $\left(Q_{e}\right)$ (window $\left(Q_{w}\right)$, door $\left(Q_{d}\right)$, wall $\left(Q_{w}\right)$ and curtain $\left(Q_{c}\right)$ ) from sensible heat $\left(Q_{m}\right)$. Then, in equation 3, total coefficient of heat conductance $(U)$ and resistance $(1 / U)$ were calculated using equation 7 for roof. In equation 6 , thickness of each material used on the roof (Table 2) was divided by its coefficient of heat conductance, except insulation material and summed plus 1/fi and 1/fo. Total resistance of roof was subtracted from the summed resistance of each roof element and when the obtained value was multiplied by coefficient of heat conductance of glass wool, its thickness was found.

As a result of aforementioned calculation, the insulation material on the roof was calculated as $5.02 \mathrm{~cm}$ to provide heat and humidity balance in the planned tom turkey house. Since there was no $5.02 \mathrm{~cm}$ glass wool in market, a $6 \mathrm{~cm}$ glass wool was chosen instead.

Table 2 Physical properties of some materials used on roof (Anonymous, 1987; Balaban \& Sen, 1988)

\begin{tabular}{lcc}
\hline Materials & Coefficient, $\mathrm{c}_{\mathrm{m}}\left(\mathrm{W} / \mathrm{m}^{2}{ }^{\circ} \mathrm{C}\right)$ & Thickness, $\mathrm{d}_{\mathrm{m}}(\mathrm{m})$ \\
\hline Wooden cover & 0.2 & 0.02 \\
Bitumen felt & 0.139 & 0.001 \\
Asbestos & 0.465 & 0.004 \\
Glass wool & 0.04 & 0.05
\end{tabular}

Surface coefficients of inside (fi) and outside (fo) heat conductance of roof 8.14 and $23.26\left(\mathrm{~W} / \mathrm{m}^{2}{ }^{\circ} \mathrm{C}\right)$.

After the tom turkey house had been planned, the probability of outdoor temperature (average temperatures for January, February, August and September for the period 1980 - 2007 are given in Figure 1) and RH to estimate heat and humidity balance in the tom turkey house were calculated using the Weibull Method (Tulucu, 1988). To apply this method, long-term monthly outdoor temperature data were used. As a result of this calculation, the coldest and warmest months were determined as crucial months with a contingency of $80 \%$. Thus, tom turkey growing periods coinciding with these critical months were determined.

Tom turkey poults are generally housed in brooder houses from one day to eight weeks of age (Feddes $\&$ McDermott, 1992) after which they are transferred to grower houses until $16-20$ weeks of age. In the first four weeks, turkey poults are very sensitive to inside temperature and humidity. For this reason, a general heat balance equation (Carr, 1980; Balaban \& Sen, 1988; Ibrahim et al., 1991; ASAE, 1996; Lidley \& Whitaker, 1996) was used to calculate supplementary heat required for periods of five weeks for the critical coldest and hottest months of the year. In the calculation, relative humidity was assumed to be $65 \%$ in the house (Konca, 2001; Turkoglu et al., 2005). The values of outside air RH measured in the same region were used. Temperature, sensible heat of turkey poults for body weights corresponding to this air temperature, total heat and moisture production values, in Table 3, were taken from ASAE (1996). Within the first four 


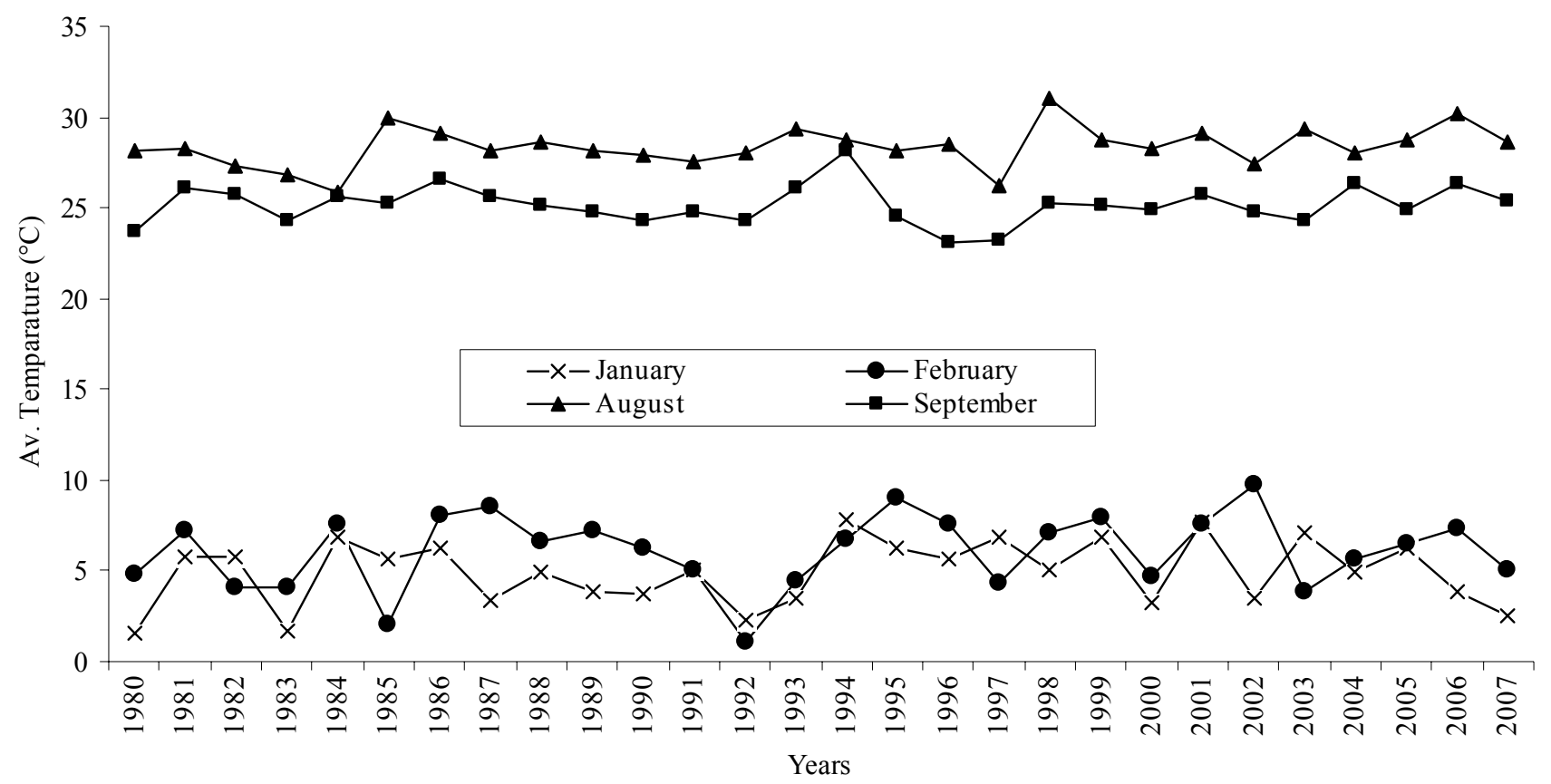

Figure 1 Monthly average temperatures in Kahramanmaras for four months of the year over 27 years.

Table 3 Climate data providing environmental conditions inside the tom turkey house

\begin{tabular}{|c|c|c|c|c|c|c|c|c|c|}
\hline \multirow{2}{*}{ Weeks* } & \multirow{2}{*}{$\begin{array}{c}\text { *Weight } \\
(\mathrm{kg})\end{array}$} & \multirow{2}{*}{$\begin{array}{c}{ }^{*} \mathrm{Q}_{\mathrm{m}} \\
(\mathrm{W} / \mathrm{kg})\end{array}$} & \multirow{2}{*}{$\begin{array}{c}* \mathrm{~W}_{\mathrm{ac}} \\
(\mathrm{g} / \mathrm{kg}-\mathrm{h})\end{array}$} & \multicolumn{3}{|c|}{ Temperature $\left({ }^{\circ} \mathrm{C}\right)$} & \multicolumn{3}{|c|}{ Absolute Water Content $\left(\mathrm{g} / \mathrm{m}^{3}\right)$} \\
\hline & & & & $* \mathrm{t}_{\mathrm{i}}$ & $t_{0}$ & $\left(\mathrm{t}_{\mathrm{i}}-\mathrm{t}_{\mathrm{o}}\right)$ & $\mathrm{g}_{\mathrm{i}}$ & $\mathrm{g}_{\mathrm{o}}$ & $\left(g_{i}-g_{o}\right)$ \\
\hline \multicolumn{10}{|c|}{ Criteria used at start of growth period on first of January } \\
\hline 1. & 0.1 & 6.1 & 15.6 & 35 & 6.5 & 28.5 & 25.8 & 4.9 & 20.8 \\
\hline 2. & 0.2 & 6.3 & 9.8 & 32 & 6.5 & 25.5 & 22.2 & 4.9 & 17.2 \\
\hline 3. & 0.4 & 5.4 & 7.2 & 29 & 6.5 & 22.5 & 18.8 & 4.9 & 13.9 \\
\hline 4. & 0.6 & 5.9 & 4.1 & 27 & 6.5 & 20.5 & 16.9 & 4.9 & 12.0 \\
\hline 5. & 1.0 & 6.3 & 2.4 & 24 & 7.8 & 16.2 & 14.2 & 5.4 & 8.9 \\
\hline
\end{tabular}

$\begin{array}{llllllllll}\text { 1. } & 0.1 & 6.1 & 15.6 & 35 & 29.2 & 5.8 & 25.8 & 18.9 & 6.8 \\ \text { 2. } & 0.2 & 6.3 & 9.8 & 32 & 29.2 & 2.8 & 22.2 & 18.9 & 3.2 \\ \text { 3. } & 0.4 & 5.4 & 7.2 & 29 & 29.2 & -0.2 & 18.8 & 18.9 & -0.2 \\ \text { 4. } & 0.6 & 5.9 & 4.1 & 27 & 29.2 & -2.2 & 16.9 & 18.9 & -2.1 \\ \text { 5. } & 1.0 & 6.3 & 2.4 & 24 & 26.0 & -2.0 & 14.2 & 15.9 & -1.7\end{array}$

*: Data were taken from ASAE (1996), $\mathrm{Q}_{\mathrm{m}}$ is the sensible heat dissipated by the tom turkey poults, $\mathrm{W}_{\mathrm{ac}}$ is the moisture production per unit weight of poult, $t_{i}$ and $t_{o}$ are the inside and outside temperature of house, $g_{i}$ and $g_{o}$ are the inside and outside temperature of house, $\mathrm{g}_{\mathrm{i}}$ and $\mathrm{g}_{\mathrm{o}}$ are inside and outside of the house absolute air moisture. 
weeks of the growing season the supplementary heat requirement per poult was calculated for an area of $0.05 \mathrm{~m}^{2}$ (Arrington, 1980; Turkoglu et al., 2005). The total area was calculated as $0.05 \mathrm{~m}^{2} \times 6500=325 \mathrm{~m}^{2}$. In order to use heat economically, only this area was subjected to supplementary heat application. The house was divided into two areas using $1 \mathrm{~mm}$ PVC curtains, and the coefficient of heat conductance was $4.7 \mathrm{~W} / \mathrm{m}^{2}$ ${ }^{\circ} \mathrm{C}$ (Zabeltitz, 1995). However, the area surrounded by curtains was $329 \mathrm{~m}^{2}$ (Table 2) since curtains attached to the truss were installed at $3 \mathrm{~m}$ intervals. The area surrounded by the curtains was therefore a little larger than the estimated area. As tom turkey poults grow, they need more space and after the fourth week of the growing season the required supplementary heat area was recalculated for an area of $0.11-0.12 \mathrm{~m}^{2}$. At that stage the curtains were removed.

\section{Results and Discussion}

Using the Weibull Method (Tulucu, 1988) the warmest and coldest crucial months, with a contingency of $80 \%$, in Kahramanmaras were determined as August $\left(29.2{ }^{\circ} \mathrm{C}\right)$ and January $\left(6.5{ }^{\circ} \mathrm{C}\right)$, respectively (Figure 1 and Table 3), and for these months heat and moisture balances were calculated.

Total heat conductance coefficients for walls, doors, windows, curtains and roof (calculated for $6 \mathrm{~cm}$ glass wool) were $2.08,4.07,6.98$ and $6.03,0.53 \mathrm{~W} / \mathrm{m}^{2}{ }^{\circ} \mathrm{C}$, respectively. Maximum heat conductance coefficient of the structural elements was calculated as $2.14 \mathrm{~W} / \mathrm{m}^{2}{ }^{\circ} \mathrm{C}$ in the critical coldest month by using a $65 \%$ inside RH of tom turkey houses, and outside temperature value that was predicted from the mean long term monthly outside temperature with $80 \%$ probability. Inside temperature values obtained from ASAE (1996) are given in Table 3. Heat conductance coefficients for walls and roof were calculated as 2.08 and $0.53 \mathrm{~W} / \mathrm{m}^{2}{ }^{\circ} \mathrm{C}$. It was determined that no condensation would be expected on the surface of walls and roof since the calculated heat conductance coefficients were smaller than the maximum heat conductance coefficients $\left(\mathrm{U}_{\max }\right)$. If the $\mathrm{U}_{\max }$ is less than the calculated heat conductance coefficient, condensation occurs on the structural elements, causing undesired conditions such as flaking of paint, rotting of wooden structural elements and water absorption into insulation materials, which reduce their resistance properties. It was also determined that using insulation for the roof was sufficient to supply optimum inside environmental conditions.

The required supplementary heat in the tom turkey poult houses was calculated as the difference between the heat loss from structural elements and ventilation, and the heat emitted by the poults. The amount of heat loss from structural elements varies according to the difference between indoor and outdoor temperatures and the insulation thickness, and the coefficient of thermal conductivity. The amount of supplementary heat required was calculated using $6 \mathrm{~cm}$ thick glass wool on the roof of the house; the results being given in Tables 4 and 5. The last columns of Tables 4 and 5 show the amount of supplementary heat

Table 4 Heat and humidity production* according to tom turkey poult weight, heat losses from structural elements and supplementary heat when brooding started on the first of January

\begin{tabular}{|c|c|c|c|c|c|c|c|c|c|c|c|c|}
\hline \multirow[b]{2}{*}{ Weeks } & \multirow{2}{*}{$\begin{array}{l}\text { Weight } \\
(\mathrm{kg})\end{array}$} & \multirow{2}{*}{$\begin{array}{c}\mathrm{Q}_{\mathrm{m}} \\
(\mathrm{w} / \mathrm{kg})\end{array}$} & \multirow{2}{*}{$\begin{array}{c}W_{a} \\
(g / h)\end{array}$} & \multirow{2}{*}{$\underset{\left(\mathrm{m}^{3} / \mathrm{h}\right)}{\mathrm{Q}_{\min }}$} & \multicolumn{7}{|c|}{ Heat losses from structural elements } & \multirow{2}{*}{$\begin{array}{l}\mathrm{Q}_{\text {sup }} \\
\text { (W) }\end{array}$} \\
\hline & & & & & $\begin{array}{c}\mathrm{Q}_{\mathrm{v}} \\
(\mathrm{W})\end{array}$ & $\begin{array}{l}\mathrm{Q}_{\text {win }} \\
(\mathrm{W})\end{array}$ & $\begin{array}{c}\mathrm{Q}_{\mathrm{d}} \\
(\mathrm{W})\end{array}$ & $\begin{array}{c}\mathrm{Q}_{\mathrm{w}} \\
(\mathrm{W})\end{array}$ & $\begin{array}{c}\mathrm{Q}_{\mathrm{c}} \\
(\mathrm{W})\end{array}$ & $\begin{array}{c}\mathrm{Q}_{\mathrm{r}} \\
(\mathrm{W})\end{array}$ & $\begin{array}{c}\mathrm{Q}_{\mathrm{e}} \\
(\mathrm{W})\end{array}$ & \\
\hline 1. & 0.1 & 3965 & 10140 & 487 & 4731 & 9847 & 255 & 9959 & 6599 & 5510 & 32171 & -32937 \\
\hline 2. & 0.2 & 8190 & 12740 & 740 & 6433 & 8811 & 228 & 8911 & 5905 & 4930 & 28784 & -27028 \\
\hline 3. & 0.4 & 14040 & 18720 & 1351 & 10363 & 7774 & 202 & 7862 & 5210 & 4350 & 25398 & -21721 \\
\hline 4. & 0.6 & 23010 & 15990 & 1337 & 9346 & 7083 & 184 & 7164 & 4747 & 3964 & 23140 & -9476 \\
\hline 5. & 1.0 & 40950 & 15600 & 1759 & 9716 & 12721 & 541 & 12468 & 3751 & 7154 & 36634 & -5400 \\
\hline
\end{tabular}

* Data were taken from ASAE (1996), $\mathrm{Q}_{\mathrm{m}}$ is the sensible heat production, $\mathrm{W}_{\mathrm{a}}$ is the total moisture production, $\mathrm{Q}_{\mathrm{v}}$ is the loss of heat removed by ventilation, $Q_{w i n}$ is the loss of heat through windows, $Q_{d}$ is the loss of heat through doors, $Q_{w}$ is the loss of heat through walls, $Q_{c}$ is the loss of heat through curtains, $Q_{r}$ is the loss of heat through roof, $Q_{\text {sup }}$ is the supplementary heat. 
Table 5 Heat and humidity production* according to tom turkey poult weight, heat losses from structural elements and supplementary heat when brooding started on the first of August

\begin{tabular}{|c|c|c|c|c|c|c|c|c|c|c|c|c|}
\hline \multirow[b]{2}{*}{ Weeks } & \multirow{2}{*}{$\begin{array}{c}\text { Weight } \\
(\mathrm{kg})\end{array}$} & \multirow{2}{*}{$\begin{array}{c}\mathrm{Q}_{\mathrm{m}} \\
(\mathrm{w} / \mathrm{kg})\end{array}$} & \multirow{2}{*}{$\begin{array}{c}W_{a} \\
(g / h)\end{array}$} & \multirow{2}{*}{$\begin{array}{c}\mathrm{Q}_{\min } \\
\left(\mathrm{m}^{3} / \mathrm{h}\right)\end{array}$} & \multicolumn{7}{|c|}{ Heat losses from structural elements } & \multirow{2}{*}{$\begin{array}{l}\mathrm{Q}_{\text {sup }} \\
\text { (W) }\end{array}$} \\
\hline & & & & & $\begin{array}{c}\mathrm{Q}_{\mathrm{v}} \\
(\mathrm{W})\end{array}$ & $\begin{array}{l}\mathrm{Q}_{\text {win }} \\
(\mathrm{W})\end{array}$ & $\begin{array}{c}\mathrm{Q}_{\mathrm{d}} \\
(\mathrm{W})\end{array}$ & $\begin{array}{l}\mathrm{Q}_{\mathrm{w}} \\
(\mathrm{W})\end{array}$ & $\begin{array}{c}\mathrm{Q}_{\mathrm{c}} \\
(\mathrm{W})\end{array}$ & $\begin{array}{c}\mathrm{Q}_{\mathrm{r}} \\
(\mathrm{W})\end{array}$ & $\begin{array}{c}\mathrm{Q}_{\mathrm{e}} \\
(\mathrm{W})\end{array}$ & \\
\hline 1. & 0.1 & 3965 & 10140 & 1498 & 2962 & 2004 & 51.9 & 2027 & 1343 & 1121 & 6547 & -5544 \\
\hline 2. & 0.2 & 8190 & 12740 & 4032 & 3849 & 967 & 25.1 & 978 & 648 & 541 & 3161 & 1180 \\
\hline 3. & 0.4 & 14040 & 18720 & -93600 & 6384 & -69 & -1.8 & -70 & -46 & -39 & -226 & 7882 \\
\hline 4. & 0.6 & 23010 & 15990 & -7614 & 5712 & -760 & -19.7 & -769 & -509 & -425 & -2483 & 19781 \\
\hline 5. & 1.0 & 40950 & 15600 & -9177 & 6258 & -1571 & -66.7 & -1539 & -463 & -883 & -4523 & 39214 \\
\hline
\end{tabular}

* Data were taken from ASAE (1996), $\mathrm{Q}_{\mathrm{m}}$ is the sensible heat production, $\mathrm{W}_{\mathrm{a}}$ is the total moisture production, $\mathrm{Q}_{\mathrm{v}}$ is the loss of heat removed by ventilation, $Q_{w i n}$ is the loss of heat through windows, $Q_{d}$ is the loss of heat through doors, $Q_{w}$ is the loss of heat through walls, $Q_{c}$ is the loss of heat through curtains, $Q_{r}$ is the loss of heat through roof, $Q_{\text {sup }}$ is the supplementary heat.

required. If the number in the last columns is negative, supplementary heat is needed, but if the number is positive there is no need for supplementary heat. As can be seen from Table 4, if brooding is started on January 1, there will be a need to supply an additional 32937, 27028, 21721, 9476 and $5400 \mathrm{~W}$ in the first five weeks, respectively. As poults increase in body weight, the need for supplementary heat decreases, since total heat production by the poults increases with body weight, which would increase the air temperature inside the house (Gates et al., 1996; Pederson \& Thomsen, 2000).

When brooding of tom turkey poults is started on August 1, results of this study show that there will be no need for heating except in the first week of the growing period. As seen in Table 5, the required heat by tom turkey poults for the first week, under the given conditions, was calculated as $5544 \mathrm{~W}$. However, there may be an advantage in providing supplementary heat to poults up to three weeks of age since they have not fully feathered, and their digestive system is not fully developed until 2 - 3 weeks of age (Carew et al., 1972; North, 1984; Chen \& Chiang, 2005). The heat increment of digestion is considerably lower in early life of poults due to incomplete development of the digestive system. Thus, a relatively higher temperature is preferred in this period. The minimum and maximum temperatures during this time period should be 29 and $32{ }^{\circ} \mathrm{C}$, respectively. Although, as mentioned before, our research results reveal that there is no need of supplementary heat for the second and third weeks, it should be provided whenever the inside temperature decreases below $29{ }^{\circ} \mathrm{C}$ (Tables 4 and 5). Carr et al. (1976) determined that poults need higher supplementary heat up to 3 - 4 weeks while Thomason et al. (1987) suggested that poults should be kept in a well conditioned environment for the first two weeks of age. This result shows that ASAE standards such as weight development, sensible heat, moisture production and inside temperature may be insufficient to calculate supplementary heat requirement of tom turkey poults. For example, Xin et al. (1998) reported that heat and moisture production standards date back 20 to 40 years, and remarkable changes had subsequently taken place in animal genetics, nutrition, housing equipment and management schemes. Such changes could significantly alter the heat and moisture production characteristics of the animals and their housing facilities. In comparison with the ASAE standards for tom turkey body weights of $0.1-1.0 \mathrm{~kg}$, Xin et al. (1998) reported a 2 to $49 \%$ higher total heat production, a 4 to $282 \%$ higher moisture production and 2 to $107 \%$ lower sensible heat production. In addition, Gencoglan et al. (2005) determined that ASAE standards were not suitable in the calculation of supplementary heat requirement for broilers.

\section{Conclusion}

If brooding of tom turkey poults is started on the first of January in the Kahramanmaras region of Turkey, and a $6 \mathrm{~cm}$ thickness of glass wool is used for insulation, additional heating will be needed during the first five weeks of growth. If brooding is started on August, there will be no need of extra heating except in the first week of the growing period, according to ASEA standards. However, tom turkey poults may 
nevertheless benefit from supplementary heating since they do not produce enough heat to warm up their surroundings in the early weeks, they have not fully feathered, and their digestive system is not fully developed until 2 - 3 weeks of age. Supplementary heat should therefore be provided whenever the inside temperature decreases below $29^{\circ} \mathrm{C}$.

\section{References}

Alagoz, T., 1983. Determination of present situations of poultry housing in Cukurova region and development of suitable broiler house plans for region. Ph.D. dissertation, Univ. of Cukurova, Turkey (in Turkish).

Albright, L.D., 1990. Environment Control for Animals and Plants. An ASAE Textbook, The American Society of Agricultural Engineers, 2950 Niles Road St. Joseph, Michigan 49085- 9659, USA.

Anonymous, 1987. Animal Houses - rules for isolation and heating TS 5087, Turk Standards Institute. Necati Bey Evanue No: 112, Bakanliklar-Ankara. pp. 1-12 (in Turkish).

Arrington, L.C., 1980. Market turkey management-brooding. College of Agricultural and Life Science, University of Wisconsin-Madison and Division of Economic and Environmental Development, University of Wisconsin Extension, USA.

ASAE, 1996. Agricultural Standards, ASAE, $41^{\text {st }}$ Ed. 2950 Niles Road, ST Joseph Michigan, USA.

Balaban, A. \& Sen, E., 1988. Agricultural Structures. Ankara Univ. Agricultural Faculty Publication No: 1083, Course Book No: 311, Ankara. 244 pp. (in Turkish).

Bolla, G., 2005. Raising Turkeys. NSW Department of Primary Industries/Agriculture. http://www.agric.nsw.gov.au/reader/ 202.

Borges, S.A., Fischer da Silva, A.V., Ariki, J.D., Hooge, M. \& Cummings, K.R., 2003. Dietary electrolyte balance for broiler chickens exposed to thermoneutral or heat-stress environments. Poult. Sci. 82, 428-435.

Carew, L.B., Machemer, R.H., Sharp, R.W. \& Foss, D.C., 1972. Fat absorption by the very young poults. Poult. Sci. 51, 738-742.

Carr, E.L., 1980. High density brooding of broilers. Trans. of the ASAE. 23, 658-666.

Carr, L.E., Carter, T.A. \& Felton, K.E., 1976. Low temperature brooding of broilers. Trans. of the ASAE. 19, 553-555.

Charles, D.R., 1981. Practical ventilation and temperature control for poultry. In: Environmental Aspects of Housing for Animal Production. Ed. Clark, J.A., University of Nottingham, Butterworths, London. pp. 183-195.

Chen, H.Y. \& Chiang, S.H., 2005. Effect of dietary polyunsaturated/saturated fatty acid ratio on heat production and growth performance of poults under different ambient temperature. Anim. Feed Sci. Technol. 120, 299-308.

CIGR, 1984. Climatisation of animal houses. Report of Working Group. Scottish Farm Building Investigation Unit. Scottopress Publishers Limited, 15 Marberly Street, Craibstone, Aberdeen, Scotland, UK. pp. 1-72.

El Bousy, A.R. \& Van Marle, A.L., 1978. The effects of climate on poultry physiology in tropics and their improvement. Wrld's Poult. Sci. J. 34, 155-170.

Ernst, R.A., 1995. Housing for improved performance in hot climates. In: Poultry Production in Hot Climates. Ed. Daghir, N.J., Cab International, Wallingford, UK. pp. 72-82.

Feddes, J.J.R. \& McDermott, K., 1992. Turkey heat production measured directly and indirectly under commercial-scale conditions. Can. Agric. Engng. 34, 259-265.

Gates, R.S., Overhults, D.G. \& Zhang, S.H., 1996. Minimum ventilation for modern broiler facilities. Trans. of the ASAE. 39, 1135-1144.

Gencoglan, S., Gencoglan C. \& Cicek Rathert, T., 2005. Calculation of supplementary heat required in a broiler house in Kahramanmaras region (Turkey). Arch. Geflugelk. 69, 84-89.

Haartsen, P.I., 1981. Aspects of heating animal houses. In: Environmental Aspects of Housing for Animal Production. Ed. Clark, J.A., University of Nottingham, Butterworths, London. pp. 413-421.

Hurwitz, S. \& Bengal, I., 1982. Energy use and performance of young turkeys kept under various constant and cycling environmental temperatures. Poult. Sci. 61, 1082-1086. 
Hurwitz, S., Weisselberg, M., Eisner, U., Bartov, I., Risenfeld, G., Sharvit, M., Niv, A. \& Bornstein S., 1980. The energy requirements and performance of growing chickens and turkeys as affected by environmental temperature. Poult. Sci. 59, 2290-2299.

Ibrahim, M.H., Stewart, L.E. \& Carr, L.E., 1991. A model for the heat pump brooding of broilers. Trans. of the ASAE. 34, 1873-1878.

Konca, Y., 2001. Turkey Brooding. Agricultural Research and Education Coordination (TAYEK/TYUAP), Proc. Animal Working Group Meeting in 2001. Ege Agricultural Research Institute Directorate, 27-29 March, Izmir, Publ. No: 100. pp. 21-31. (in Turkish).

Lindley, J.A. \& Whitaker J.H., 1996. Agricultural Building and Structures. ASAE, Publisher St. Joseph, MI, USA.

Miles, R.D., 1999. Understanding heat stress in poultry and strategies to improve production through good management and maintaining nutrient and energy intake. Nutrition and Management Department of Dairy and Poultry Sciences University of Florida Gainesville. pp. 1-20.

North, M.O., 1984. Commercial Chicken Production Manual: Poultry Housing. AVI Publishing Company, Inc. Westport, Connecticut. pp. 148-177.

Okuroglu, M. \& Delibas L., 1987. Structure elements project criteria in barns. Poult. J. 55. (in Turkish).

Ones, A. \& Olgun, M., 1989. Designing Criteria of Farm Structures. The Ministry of Public Works and Settlement Bulletin. 21 (104), Ankara. pp. 27-35. (in Turkish).

Osbaldiston, G.W. \& Sainsbury, D.W.B., 1963. Control of the environment in a poultry house. The principles and practice. Part I. Vet. Rec. 75, 7.

Ozen, N., 1992. Poultry Brooding. Republic of Turkey, Ministry of Agriculture \& Rural Affairs, Kahramanmaras Provincial Agricultural Directorate, Farmer Education and Extension Branch. Farmer Brochure No: 1 (in Turkish).

Pedersen, S. \& Thomsen, M.G., 2000. Heat and moisture production of broilers kept on straw bedding. J. Agric. Engng. Res. 75, 177-187.

Scott, N.R., DeShazer, J.A. \& Roller, W.L., 1983. Effect of thermal and gaseous environment on livestock. In: Ventilation of Agricultural Structures. Eds Hellickson, M. A. \& Walker, J.N., The American Society of Agricultural Engineers, 2950 Niles Road St. Joseph, Michigan 49085- 9659, USA. pp.121-165.

Stull, C., 1998. Animal Care Series. Turkey Care Practices (2nd ed.). California Poultry Workgroup, Univ. of California, Cooperative Extension. Published by the Univ. of California, Davis. pp. 1-25.

Thomason, D.D.M., Lepley, K.C. \& Dendy, M., 1987. American Soybean Association Poultry Brooding, USA. pp. 65.

Tulucu, K., 1988. Applied Hydrology. Univ. of Cukurova, No: 76, Adana. pp. 39-51 (in Turkish).

Turkoglu, M., Sarica, M. \& Eleroğlu H., 2005. Turkey Brooding. Publisher by Otak Form-Ofset Samsun, Turkey (in Turkish).

Xin, H., Chepete, H.J., Shao J. \& Sell, J.L., 1998. Heat and moisture production and minimum ventilation requirements of tom turkeys during brooding-growing period. Trans. of the ASAE. 41, 1489-1498.

Yahav, S., Straschnow, A., Plavnik, I. \& Hurwitz, S., 1996. Effect of diurnal cyclic versus constant temperatures on chicken growth and food intake. Br. Poult. Sci. 37, 43-54.

Yahav, S., Straschnow, A., Plavnik, I. \& Hurwitz, S., 1997. Blood system response of chickens to changes in environmental temperature. Poult. Sci. 76, 627-633.

Yalcın, S., Settar, P., Ozkan, S. \& Cahaner, A., 1997. Comparative evaluation of 3 commercial broiler stocks in hot vs temperate climates. Poult. Sci. 76, 921-929.

Zabeltitz, C.V., (Translator Baytorun, A.N.) 1995. Greenhouses. Univ. of Cukurova, Faculty of Agriculture General publication No: 110, Course Book Publication No: 29, Adana. (in Turkish). 